\title{
PEMBERDAYAAN MASYARAKAT MELALUI DIVERSIFIKASI PRODUK KELADI DAN SINGKONG
}

\section{COMMUNITY EMPOWERMENT THROUGH DIVERSIFICATION OF TARO AND CASSAVA BASED PRODUCTS}

\author{
${ }^{1)}$ Renny Anggraini, ${ }^{2)}$ Fera Maulina, ${ }^{3)}$ Vivi \\ ${ }^{1)}$ Program Studi Budidaya Tanaman Pangan, \\ ${ }^{2,3)}$ Program Studi Bussiness English, Politeknik Tonggak Equator \\ J1. Fatimah No. 1-2, Pontianak, Kalimantan Barat \\ email: ynner@yahoo.com
}

\begin{abstract}
ABSTRAK
Singkong dan talas menjadi komoditi utama di Dusun Lingga Selatan, Desa Lingga Kecamatan Sungai Ambawang Kabupaten Kubu Raya Kalimantan Barat, namun karena daerah yang jauh sehingga sulit dijangkau walaupun Desa Lingga sendiri tidak jauh dari kota. Dusun Lingga Selatan perlu waktu 45 menit untuk menjangkau pusat desa dan jalan yang sulit ditempuh ketika hujan. Hal inilah yang menjadi kendala untuk hasil pertanian cepat dijual. Oleh karena itu masyarakat Dusun Lingga Selatan Desa Lingga memerlukan teknologi untuk memperpanjang umur simpan hasil pertanian yaitu keladi dan singkong sehingga ketika panen tidak cepat rusak mutunya dan umur simpannya menjadi lebih panjang. Tujuan dari kegiatan ini adalah untuk meningkatkan pendapatan masyarakat petani singkong dan keladi di Desa Lingga dan menambah nilai ekonomi kedua produk pangan tersebut. Metode yang digunakan adalah pelatihan dan pendampingan pada bidang produksi, manajemen dan pemasaran produk keladi dan singkong. Hasil kegiatan menunjukkan bahwa masyarakat mitra telah memahami tahapan dan cara produksi tepung keladi dan singkong, mie singkong, dan cookies keladi. Masyarakat mitra tertarik untuk memproduksi untuk dijual maupun hanya sebagai konsumsi rumah tangga.
\end{abstract}

Kata kunci : Singkong, Keladi, Pelatihan, Produksi

\begin{abstract}
Taro and cassava are the main commodities of Dusun Lingga Selatan, Lingga Village, Sungai Ambawang Sub-District, District of Kubu Raya. It is located in a remote area although it's not far from Pontianak city. It is needed 45 minutes to reach Desa Lingga itself and needed 40 minutes more to reach Dusun Lingga Selatan with slippery and broken path when rain falls. Therefore, Lingga Village Community needed some technologies to extend the shelf life of taro and cassava crops due to prevent it from rapid deterioration that affected its quality. This community service aimed to increase taro and cassava farmers community income and improving the economic value of those products. The method used in this project were training and accompaniment of production, management, and marketing of taro and cassava-based products. The results showed that the community understood every step of producing taro and cassava flour, cassava noodles, and taro cookies. They were also interested in producing it to be marketed as well as to be consumed.
\end{abstract}

Keywords: Cassava, Taro, Training, Production

Submited : 28 Juli $2018 \quad$ Revision : 11 Desember $2018 \quad$ Accepted : 14 Desember 2018

\section{PENDAHULUAN}

Kecamatan Sungai Ambawang adalah kecamatan yang terletak di Kabupaten Kubu Raya yang merupakan
Kabupaten terdekat dari Kota Pontianak. Salah satu desa di Kecamatan Sungai Ambawang adalah Desa Lingga. Desa Lingga terletak di perlintasan jalan 
Renny Anggraini, Fera Maulina, Vivi Pemberdayaan Masyarakat Melalui Diversifikasi Produk Keladi Dan Singkong

propinsi yang juga merupakan jalan lintas negara (Indonesia-Malaysia), hal ini menjadikan kawasan tersebut terbuka untuk pengembangan ekonomi masyarakat. Peluang tersebut tidak serta-merta diiringi dengan kemajuan masyarakat baik berupa teknologi, wawasan, maupun kesejahteraan. Hal ini dapat dilihat dari keadaan penduduk Desa Lingga di mana $34,15 \%$ termasuk dalam keluarga miskin, sedangkan $11,63 \%$ digolongkan sebagai kelompok pra sejahtera (BPPKB Kabupaten Kubu Raya, 2011).

Pada dasarnya Desa Lingga memiliki berbagai potensi yang dapat dikembangkan. Pada tahun 2015, Kecamatan Sungai Ambawang menghasilkan 229,54 kuintal/Ha tanaman pangan selain padi (BPS, 2016). Dua di antara tanaman pangan yang dihasilkan di Kecamatan Sungai Ambawang khususnya Desa Lingga adalah keladi dan singkong. Menurut penuturan Kepala Desa Lingga, Bapak Hendrikus, bahwa masyarakat Dusun Lingga Selatan memerlukan teknologi untuk memperpanjang umur simpan hasil pertanian yaitu keladi dan singkong sehingga ketika panen tidak cepat rusak mutunya dan umur simpannya menjadi lebih panjang.

Teknologi yang diperlukan untuk memperpanjang umur simpan keladi dan singkong serta dapat meningkatkan nilai ekonominya yaitu dengan mengolah kedua produk tersebut menjadi tepung maupun olahan tepung itu sendiri. Teknologi penepungan merupakan suatu metode pengolahan yang menghasilkan produk setengah jadi dengan menghaluskan bahan padat menjadi partikel-partikel yang lebih kecil sehingga mudah diaplikasikan sebagai bahan pangan. Tepung mempunyai beberapa keunggulan, antara lain: lebih mudah dalam penyimpanan, umur simpan lebih lama, penggunaanya lebih luas, lebih mudah difortifikasi, dan lebih mudah bercampur dengan bahan lain (komposit) (Marta, 2011). Oleh sebab itu salah satu teknologi yang ditawarkan untuk memperpanjang umur simpan serta meningkatkan nilai ekonomi keladi dan singkong adalah teknologi penepungan menjadi bahan setengah jadi diikuti oleh teknologi pengolahan tepung tersebut menjadi bahan jadi seperti cookies dan mie.

Usaha pengolahan tepung komposit dinilai layak dengan indikator $\mathrm{R} / \mathrm{C}$ ratio sebesar 1,49 karena dapat meningkatkan pendapatan petani (Elisabethet. al., 2014).Selain itu teknologi pengemasan juga dapat diaplikasikan sebagai pendukung teknologi penepungan dan pengolahan tepung menjadi bahan jadi untuk memperpanjang umur simpan produk tersebut. Menurut Elisabeth et. al.(2014), tepung komposit yang disimpan dalam kemasan PE $40 \mathrm{~mm}$ pada suhu $20^{\circ} \mathrm{C}$ memiliki umur simpan sekitar 22 minggu.Tujuan dari kegiatan ini adalah untuk meningkatkan pendapatan masyarakat petani singkong dan keladi di Desa Lingga dan menambah nilai ekonomi kedua produk pangan tersebut.

\section{METODE}

Mitra kegiatan PKM ini adalah kelompok Pengajian Petani Keladi dan Singkong, serta kelompok PKK Desa Lingga. Mitra 1 aktif dalam kegiatan usaha tani palawija yaitu keladi dan singkong. Rata-rata mitra 1 memiliki lahan seluas 1 ha yang sebagian bahkan sepenuhnya ditanami keladi dan singkong. Mitra 1 berpotensi dalam berperan sebagai produsen tepung keladi dan singkong. Sedangkan Mitra 2 merupakan organisasi nirlababeranggotakan 15 orang yang aktif menjadi ujung tombak dalam menyukseskan program pemerintah. Mitra 2 berperan menjadi penampung produk mitra 1 untuk diolah menjadi pangan jadi, selain itu mitra 2 juga berperan sebagai tenaga pemasaran Mitra 1. 
Hasil wawancara yang dilakukan dengan Bapak M. Umar selaku mitra 1, didapatkan beberapa permasalahan yang selama ini dihadapi mitra 1. Beberapa permasalahan yang dihadapi mitra 1 diantaranya adalah:

1. Kelompok tani belum mengetahui tentang strategi pemasaran sehingga singkong hanya dijual kepada pengepul atau dijual langsung bagi masyarakat yang membutuhkan sehingga harganya murah.

2. Keladi dan singkong dijual mentah sehingga keuntungan yang didapat tidak maksimal, selain itu waktu tunggu dalam memperoleh keuntungan cukup lama karena panennya lama sehingga kontinuitas usaha tidak berjalan. Hal ini disebabkan karena masyarakat belum mengetahui tentang pentingnya manajemen produksi

3. Umur simpan keladi dan singkong pendek, sedangkan waktu simpannyahingga sampai ke pasar cukup panjang sehingga mutunya berkurang seiring dengan nilai ekonomisnya.Di satu sisi petani tidak memiliki pengetahuan dan wawasan untuk diversifikasi produk.

4. Manajemen keuangan dan pemasaran usaha tani pada mitra 1 masih didasarkan intuisi dan belum dikelola dengan baik.

Hasil Wawancara dengan Ibu Saena selaku Ketua PKK Desa Lingga, didapatkan beberapa permasalahan yang dihadapi oleh mitra 2. Beberapa permasalahan tersebut antara lain adalah:

1. Pengetahuan anggota kelompok PKK masih rendah dalam mengolah bahan pangan yang berpotensi meningkatkan keragaman pangan dan keseimbangan gizi baik di dalam keluarga secara khusus maupun dalam masyarakat secara umum, padahal di masyarakat tersebut banyak sekali singkong dan keladi yang dapat menjadi sumber pangan alternatif bagi keluarga.

2. Pada saat ini ibu-ibu PKK sudah mengolah keladi dan talas hanya dengan digoreng atau dibuat keripik bahkan dibuat untuk menu arisan. Akan tetapi karena tidak adanya pengetahuan berwirausaha, keterampilan ini belum dikembangkan walaupun ada beberapa ibu-ibu yang sudah menjual untuk acara hari besar.

3. Kurangnya pengetahuan tentang pengemasan pangan terutama dalam mengemas pangan hasil olahanibu-ibu PKK tersebut seperti cookies atau kue kering dari pangan lokal yang dibuat membuat nilai jualnya masih rendah

4. Keterampilan manajemen dan pemasaran produk masih berdasarkan intuisi dan dianggap sebagai hobby saja.

Berdasarkan permasalahan mitra, beberapa metode dapat dilakukan untuk memberikan solusi. Metode yang dilakukan dalam pelaksanaan kegiatan ini dibagi menjadi beberapa bidang, antara lain:

1. Bidang Produksi

a. Memberikan pelatihan tentang pentingnya diversifikasi pangan

b. Memberikan pelatihan dan pendampingan teknologi pengolahan keladi dan singkong menjadi tepung

c. Memberikan pelatihan dan pendampingan teknologi pengolahan tepung keladi menjadi cookies

d. Memberikan pelatihan dan pendampingan teknologi pengolahan tepung singkong menjadi mie

e. Memberikan pelatihan dan pendampingan teknologi pengemasan tepung keladi dan singkong serta hasil olahannya berupa cookies dan mie

2. Bidang Manajemen: 
a. Memberikan sosialisasi perencanaan bisnis produk tepung keladi dan singkong serta olahannya berupa cookies, serta mie

b. Memberikan pendampingan perhitungan Harga Pokok Produksi produk

c. Memberikan pendampingan perhitungan harga jual produk

\section{BidangPemasaran:}

a. Memberikan sosialisasi model kemasan dan labelling yang menarik minat beli untuk produk tepung keladi dan singkong serta olahannya berupa cookiesserta mie.

b. Memberikan sosialisasi mengenai strategi pemasaran bisnis produk.

c. Memberikan pendampingan pembuatan brosur

\section{HASIL DAN PEMBAHASAN}

Adapun beberapa hasil yang dicapai dalam kegiatan ini adalah:

\section{Tahap Persiapan}

Proses kegiatan dimulai dari orientasi lapangan, di mana dilakukan diskusi dengan Kepala Desa Lingga tentang permohonan izin untuk memulai kegiatan. Selain itu dilakukan pula diskusi singkat dengan ketua RT di Dusun Lingga Selatan sebagai daerah sasaran kegiatan. Melalui diskusi, disepakati beberapa hal di antaranya waktu dan tempat kegiatan, bahan dan alat yang diperlukan selama kegiatan, dan peserta yang ditunjuk untuk mengikuti kegiatan. Selain itu didapatkan pula informasi mengenai alat-alat yang dibutuhkan untuk mempermudah pencapaian target kegiatan yang belum tersedia di tengah masyarakat.

Persiapan yang dilakukan selanjutnya adalah membuat sampel olahan singkong dan keladi berupa tepung dan olahan lanjutannya yaitu panganan berupa mie singkong dan cookies keladi, untuk dijadikan contoh jadi dalam demonstrasi yang akan dilakukan selama kegiatan. Tahapan persiapan berikutnya adalah menyediakan alat-alat yang dibutuhkan dalam mempermudah pencapaian target kegiatan.

\section{Sosialisasi}

Sosialisasi dilakukan dengan ceramah dan diskusi berupa pentingnya memperpanjang umur simpan produk singkong dan keladi. Dijelaskan pula tentang umur simpan singkong yang cukup singkat di mana jika singkong disimpan terlalu lama maka akan menghasilkan asam sianida ( $\mathrm{HCN})$ yang dapat berbahaya bagi kesehatan bila dikonsumsi bahkan dapat menyebabkan keracunan.

Disampaikan pula bahwa dengan melakukan pengolahan sederhana seperti penepungan dapat memperpanjang umur simpan produk hingga 6 bulan hingga 1 tahun bila dikemas dengan kemasan yang tepat. Metode yang digunakan dalam sosialisasi adalah metode ceramah dan diskusi, serta tanya jawab singkat mengenai materi yang telah diberikan.

Sebelum dilakukan sosialisasi, $66,67 \%$ anggota kelompok mitra tidak mengetahui tentang penanganan pasca panen singkong dan keladi, namun setelah dilakukan sosialisasi, semua anggota kelompok mitra mengetahui cara penanganan pasca panen singkong dan keladi serta manfaat pengemasan.

3. Pelatihan

Pelatihan yang dilaksanakan berupa pelatihan produksi tepung singkong, produksi tepung keladi, produksi mie singkong, dan produksi cookies keladi.

\section{Produksi Tepung Singkong}

Singkong segar dikupas secara manual dan dicuci bersih. Pengupasan kulit singkong secara manual menghasilkan umbi singkong yang tinggi, tetapi 
memerlukan waktu yang relatif lama dan tenaga kerja yang banyak (Widowati, 2011). Pencucian dilakukan menggunakan air bersih untuk menghilangkan kotoran, lendir maupun asam sianida yang terdapat pada permukaan singkong.

Singkong yang telah dicuci bersih kemudian diiris tipis menggunakan pisau atau slicer. Pengirisan dilakukan secara tipis agar singkong tidak mengalami kebusukan pada saat penjemuran, sehingga menghasilkan tepung dengan warna putih. Setelah diiris-iris, singkong dijemur selama 3-4 hari hingga kering. Singkong kering dapat segera digiling menggunakan alat discmill atau alat penepung.

Pelatihan tentang produksi tepung singkong memberikan peningkatan pengetahuan dan keberdayaan masyarakat, hal ini dapat dilihat dimana sebelum dilakukan pelatihan semua anggota kelompok mitra belum mampu memproduksi tepung singkong, sedangkan setelah dilakukan pelatihan $91,67 \%$ sudah mampu memproduksi tepung singkong setidak-tidaknya untuk konsumsi keluarga.

\section{Produksi Tepung Keladi}

Bahan utama tepung keladi berupa keladi segar yang telah dicuci, keladi kemudian dikupas secara hati-hati. Dilakukan pengukusan selama kurang lebih 5 menit pada keladi yang telah dikupas, tujuan pengukusan ini adalah untuk mengurangi kandungan asam oksalat pada keladi. Asam oksalat merupakan senyawa yang menyebabkan rasa gatal pada keladi.

Menurut Koswara (2011), rasa gatal pada saat mengonsumsi talas (keladi) disebabkan oleh tusukan jarum-jarum kristal kalsium oksalat yang terbungkus dalam suatu kapsul transparan berisi cairan yang berada diantara sel-sel umbi tersebut,kapsul-kapsul ini disebut rafid,rafid-rafid ini tertancap pada dinding pemisah antara dua vakuola pada jaringan umbi dan ujung-ujungnya berada pada vakuola tersebut,jika bagian umbi dikupas atau dipotong-potong, maka vakuola yang berisi air karena perbedaan tegangan pada kedua vakuola itu menyebabkan dinding kapsul pecah. Akibatnya kristal kalsium oksalat tersembul ke permukaan dan menusuk ke bagian kulit. Tusukan-tusukan inilah yang menyebabkan timbulnya rasa gatal pada mulut, tenggorokan, atau kulit tangan.

Setelah pengukusan selesai, umbi keladi kemudian diiris tipis lalu dijemur selama 3-4 hari hingga kering. Keladi yang telah kering langsung digiling menggunakan discmill untuk mengindari peningkatan kadar air yang dapat terjadi jika keladi disimpan lebih lama.

Pelatihan mengenai produksi tepung keladi ini terbukti dapat meningkatkan kemampuan masyarakat dalam memberdayakan pangan lokal khususnya keladi. Hal ini terlihat di mana sebelum dilaksanakan kegiatan pelatihan semua anggota kelompok belum mampu memproduksi tepung keladi, sedangkan setelah kegiatan pelatihan dilaksanakan 91,67\% anggota sudah mampu memproduksi tepung keladi meskipun hanya untuk konsumsi keluarga.

\section{Produksi Mie Singkong}

Mie singkong dibuat dengan mencampurkan bahan-bahan berupa tepung singkong, tepung terigu, tepung tapioka, garam, minyak sawit, dan air. Campuran kemudian diuleni menjadi adonan hingga kalis. Tepung terigu yang digunakan sebagai bahan campuran adalah tepung terigu berprotein tinggi, hal ini dikarenakan tepung terigu berprotein tinggi memiliki kandungan gluten yang tinggi pula sehingga adonan yang dihasilkan menjadi elastis. Berbeda dengan sifat tepung singkong yang tidak terlalu elastis sehingga sulit untuk dicetak menjadi mie bila tidak dicampur dengan tepung terigu berprotein tinggi. 
Adonan yang telah diuleni hingga

kalis kemudian dicetak menggunakan pasta maker. Setelah dicetak, dapat diolah dengan beberapa cara di antaranya adalah dengan digoreng dan direbus. Mie singkong yang digoreng menggunakan minyak dimasak dengan api kecil sehingga mie matang merata dan tidak gosong. Hasil mie pun menjadi lebih renyah dan dapat disimpan lama jika kemasan mendukung. Mie singkong yang diolah dengan cara direbus harus langsung digunakan. Pada saat perebusan mie, air rebusan dicampur sedikit minyak dengan tujuan agar mie yang direbus tidak menyatu satu dan yang lain. Mie yang telah direbus dapat langsung diolah menjadi mie ayam.

Berdasarkan hasil yang didapat di lapangan, kegiatan pelatihan pembuatan mie berbasis tepung singkong ini mampu meningkatkan pengetahuan dan kemampuan anggota kelompok mitra dalam memperluas aneka olahan tepung singkong. Hal ini terlihat dari antusiasme anggota kelompok dalam mempraktekkan sendiri pembuatan mie berbasis tepung singkong ini, di antaranya pembuatan mie ditujukan sebagai camilan sehat anak. Sebelum dilaksanakan pelatihan, semua anggota kelompok belum mengetahui cara pengolahan mie dari tepung singkong, sedangkan setelah dilakukan kegiatan, sebanyak $75 \%$ anggota kelompok sudah mampu memproduksi mie dari tepung singkong tersebut.

\section{Produksi Cookies Keladi}

Cookies Keladi dibuat dengan mencampurkan bahan-bahan berupa mentega, gula halus, kuning telur, tepung keladi, tepung susu, coklat bubuk dan soda kue. Campuran tersebut dikocok hingga rata. Berbeda dengan cookies lainnya yang menggunakan campuran tepung terigu sehingga dapat menghasilkan tekstur dari cookies yang dapat mengembang setelah dioven. Cookies yang menggunakan tepung keladi ini menghasilkan tekstur yang tidak mengembang saat dioven. Hal ini dikarenakan tepung keladi mengandung protein yang rendah dan serat pangan yang tinggi, sehingga daya serap air menjadi rendah dan adonan tidak mengembang. Protein memiliki sifat hidrofilik atau larut dalam air, hal ini yang menentukan penyerapan air dan berhubungan dengan tekstur adonan.

Adonan yang telah tercampur rata kemudian dibentuk bulatan pipih menggunakan garpu sebagai alat bantunya. Topping yang digunakan sebagai hiasan adalah taburan coco chip. Setelah dibentuk kemudian di oven dengan api kecil agar bagian dalam cookies tersebut matang dengan rata sehingga dapat menghasilkan tekstur cookies yang lebih renyah dan gurih. Tekstur yang renyah dan gurih tersebut dikarenakan kandungan serat pangan yang tinggi.

Cookies keladi memiliki indeks glikemik yang rendah sehingga lebih aman dikonsumsi oleh penderita diabetes atau penyakit degeneratif lain. Menurut Widowati (2009), umbi keladi memiliki potensi lain yaitu memiliki serat pangan yang tinggi, resisten pati tinggi, dan kaya oligosakarida, sehingga dapat membantu dalam pencegahan timbulnya penyakit degeneratif serta indeks glikemik yang rendah.

Pelatihan pembuatan cookies meningkatkan pengetahuan masyarakat mengenai diversifikasi pangan lokal khusunya keladi. Setelah dilaksanakannya pelatihan ini, $75 \%$ anggota kelompok mitra sudah mampu memproduksi cookies berbasis tepung keladi secara mandiri, dari yang sebelumnya sama sekali belum mengetahui sama sekali. Produksi cookies tepung keladi oleh anggota kelompok kebanyakan ditujukan untuk konsumsi keluarga terutama pada hari raya Idul Adha $1439 \mathrm{H}$.

\section{Pengemasan dan Pelabelan}


Pada tahapan sosialisasi telah disampaikan tentang pentingya pengemasan pada produk pertanian maupun olahannya. Setelah pelatihan produksi masing- tepung singkong, tepung keladi, mie singkong dan cookies keladi dilaksanakan, produk-produk tersebut dikemas dalam kemasan yang selain mampu memperpanjang umur simpan juga mampu menjadi daya tarik dalam pemasaran.

Produk tepung singkong dan tepung keladi di antaranya dikemas dalam plastik PP standing pouch dengan berat bersih tepung sebanyak 200 gram, sedangkan produk mie singkong dan cookies keladi dikemas menggunakan toples hardtop berbahan plastik PS food grade sehingga menjaga produk tetap renyah dan tidak mudah hancur karena didukung dengan kemasan yang kaku. Mie singkong dikemas dengan berat bersih 100 gram, sedangkan cookies keladi dikemas dengan berat bersih 150 gram.

Pelabelan dilakukan setelah produk dikemas. Sosialisasi tentang pelabelan yang dijelaskan antara lain adalah keutamaan pembuatan label, yaitu sebagai informasi produk di antaranya tertera bahan baku maupun komposisi. Manfaat label yang juga penting adalah agar produk yang telah dikemas menjadi menarik, oleh sebab itu disosialisasikan pula desain label yang dapat menarik perhatian dan meningkatkan daya jual produk.

Pelatihan mengenai pengemasan dan pelabelan mampu diterima oleh anggota kelompok mitra dengan baik. Hal ini terbukti dimana sebelum pelatihan, 91, $67 \%$ anggota belum paham betul mengenai manfaat dan penentuan pengemasan serta pelabelan yang tepat untuk produk yang dihasilkan, sedangkan setelah dilakukan kegiatan pelatihan seluruh anggota kelompok mengetahui manfaat pengemasan dan pelabelan serta dapat menentukan kemasan yang tepat sesuai produk yang dihasilkan.
5. Manajemen dan Pemasaran

Sosialisasi mengenai manajemen produk yang telah dilakukan adalah dengan memberikan informasi kepada anggota kelompok tentang harga pokok produksi dan harga jual produk berdasarkan modal yang dikeluarkan. Penetapan harga jual produk dapat mencapai $100 \%$ dari biaya modal, baik itu produk tepung singkong, tepung keladi, mie singkong, maupun cookies keladi.

Kegiatan sosialisasi pemasaran produk telah dilakukan dimana dalam kegiatan tersebut disosialisasikan mengenai strategi pemasaran bisnis produk baik secara offline maupun online. Tindak lanjut dari sosialisasi tersebut adalah kegiatan launching produk mie berbasis tepung singkong dan cookies berbasis tepung keladi pada acara peringatan hari kemerdekaan Indonesia 17 Agustus 2018 di lapangan MTS Dusun Lingga Selatan. Penjualan produk tersebut diawali dengan modal sebesar Rp 200.000,00, sedangkan omset yang dihasilkan mencapai $\mathrm{Rp}$ 393.000,00. Hal ini menunjukkan bahwa profit yang dihasilkan hampir mencapai $100 \%$ sehingga usaha ini dianggap layak untuk dilanjutkan.

Berdasarkan peningkatan kapabilitas anggota kelompok setelah sosialisasi diketahui bahwa sebanyak 91,67\% anggota kelompok mitra sudah mampu menetapkan harga jual dan menghitung laba/rugi produk yang dihasilkan serta sebanyak $75 \%$ anggota kelompok telah memperoleh keuntungan dari penjualan produk olahan setidaktidaknya $25 \%$ dari harga pokok.

\section{SIMPULAN}

Adapun simpulan yang dapat diberikan dari kegiatan adalah :

1. Masyarakat mitra telah mendapatkan informasi mengenai cara pembuatan tepung singkong dan tepung keladi, hal 
Renny Anggraini, Fera Maulina, Vivi Pemberdayaan Masyarakat Melalui Diversifikasi Produk Keladi Dan Singkong

yang digarisbawahi adalah di mana pengirisan yang tipis dalam pembuatan tepung singkong dan keladi menjadikan tepung yang dihasilkan berwarna putih

2. Masyarakat mitra telah mengetahui bahwa pengukusan pada umbi keladi yang telah dikupas bertujuan untuk mengurangi kandungan asam oksalat di dalamnya yang menyebabkan rasa gatal

3. Masyarakat mitra memahami bahwa penggunaan tepung terigu berprotein tinggi sebagai bahan pendukung tepung singkong dalam pembuatan mie bertujuan untuk mendapatkan elastisitas yang tinggi yang tidak bisa didapatkan pada karakteristik tepung singkong.

4. Masyarakat mitra memahami bahwa penggunaan tepung keladi dapat menghasilkan cookies yang bertekstur renyah dan gurih

\section{DAFTAR PUSTAKA}

Badan Pusat Statistik. (2016). Kalimantan Barat dalam Angka 2016. Pontianak: Badan Pusat Statistik Propinsi Kalimantan Barat.

Badan Pusat Statistik. (2016). Kubu Raya dalam Angka 2016. Pontianak: Badan Pusat Statistik Propinsi Kalimantan Barat.

Koswara, S. (2011). Teknologi Pengolahan Umbi-umbian. Bogor: Southeast Asian Food And Agricultural Science and Technology (SEAFAST) Center, IPB.

Elisabeth, D.A., Fawzan S.A., Jemmy R. (2015). Pendugaan Umur Simpan dan Analisis Usaha Pengolahan Tepung Komposit Keladi dan Ubi Jalar Di Bali. Prosiding Seminar Hasil Penelitian Tanaman Aneka Kacang dan Umbi.

Marta, H. (2011). Sifat fungsional dan reologi tepung jagung nikstamal serta contoh aplikasinya pada pembuatan makanan pendamping ASI. Bogor: Institut Pertanian Bogor.

Widowati, S. (2009). Tepung Aneka Umbi Sebagai Sebuah Solusi Ketahanan Pangan. Balai Besar Penelitian dan Pengembangan Pascapanen Pertanian. Bogor

Widowati, S. (2011). Proses Pengolahan Tepung Kasava dan Tapioka. Bogor: Balai Besar Penelitian dan Pengembangan Pascapanen Pertanian 